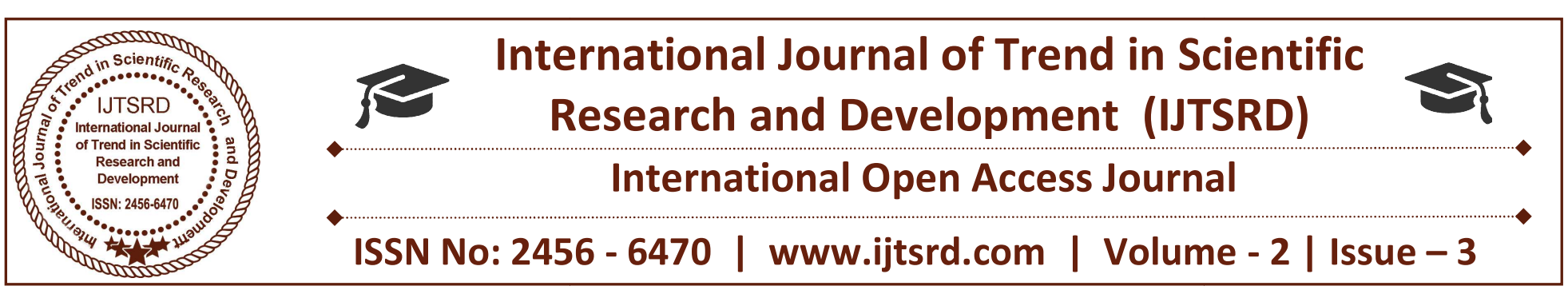

\title{
Self-help group and Women Empowerment through Bank linkage- An impact study of Himachal Pradesh
}

\author{
Sandesh Kumari \\ Research Scholar, Career Point University, \\ Kota, India
}

\author{
Vipan Kumar Bhulal \\ Assistant Professor, Government P.G. College, \\ Hamirpur, Himachal Pradesh, India
}

\section{ABSTRACT}

Women empowerment is rising as a key test for every one of the groups of a nation extraordinarily India. In various nations, women need to battle for their rights and living esteems. To beat such issues different strides have been taken by private, open and nonlegislative associations. A Self Help Group is one of these means, which is profoundly contributing in the method for women strengthening. Self improvement Gatherings offer chances to the poor women to deal with their lives through funds alongside running little scale organizations. In spite of endeavor various endeavors in the method for women strengthening, the present financial status of women in India is as yet not made strides. To determine such issues, in 1992 NABARD had approached to dispatch Self Help Group's and bank linkage program. Through such projects the financial status of poor women has been elevated. This is well demonstrated reality over the world. SHG and bank linkage program are giving different beneficial work openings, sparing open doors, safe acknowledge offices and subsequently destitution can be annihilated. However, such program had begun in all districts in all territory of India. In this manner, in the best approach to get to the accomplishment of these projects in provincial India, an endeavor will be made to think about the pre and post financial state of women SHG individuals from the Country. The present paper is to ponder the effect of Bank Linkage with Self Help Groups in women strengthening in the Hamirpur district of state Himachal Pradesh.

Keywords: $N A B A R D, S H G, B L P, R B I$

\section{INTRODUCTION}

Self Help Groups comprises of 10-20 individuals could be all women, all men or a blended gathering. SelfHelp Groups might be enrolled or unregistered. It ordinarily includes a gathering of smaller scale business people having homogenous social and monetary foundations; all willfully meeting up to spare consistent little wholes of cash, commonly consenting to add to a typical reserve (between Rs. 10 to Rs.200 every month) and to meet their crisis needs on the premise of common offer assistance. They pool their assets to end up noticeably monetarily steady, taking advances from the gathering individuals utilize aggregate astuteness and associate weight to guarantee appropriate end utilization of credit and auspicious reimbursement. Individuals make little consistent investment funds commitments over a couple of months until there is sufficient capital in the gathering to start loaning. The poor gather their reserve funds and spare it in banks. Consequently they get simple access to advance with a little rate important to begin their miniaturized scale unit endeavour. A large number of poor people and the underestimated populace in India are building their lives; their families and their general public through Self-help gatherings. Self Help Groups (SHGs) Bank Linkage Program is rising as a practical instrument for giving budgetary support of the "Unreached Poor" which has been fruitful not just in addressing money related requirements of provincial poor women yet in addition reinforce aggregate self improvement limits of poor people, prompting their strengthening. Subsequently, interest of women in the nation' monetary improvement is expanding. They additionally assume an essential part in raising the 
monetary status of their families. This has driven lift to the procedure of women' strengthening. We can follow the birthplace of the idea of SHGs in Bangladesh.

\section{Impact of SHG's in the process of empowerment of women}

The year 1975 was pronounced as a time of women. Likewise the decade from 1975 to 1985 was proclaimed as years for women. Amid this period the development for strengthening of women got fillip. The significance of part of women, which comprise half of the general public, was featured in this traverse of period. It was accentuated that lady ought to get an indistinguishable open doors from that to men.

The year 2001 was announced as a time of women strengthening. Exertion were being made toward the path that women ought to have a part in all kinds of different backgrounds, and extraordinary arrangements ought to be made in the financial plan for exercises identified with the advancement of women. Many plans were arranged and to be executed, at government level in regard of women training laws in regards to counteractive action of abominations on women, their cooperation in financial and political circles and so on. SHG development additionally began and in a route travel towards women strengthening started.

\section{SHG's in Himachal Pradesh}

Himachal Pradesh truly "snow-arrive" is a territory of India situated in Northern India. The state has 12 District. The state has a few valleys and around 90\% of the populace lives in country ranges. Shimla locale has the biggest urban populace in the state at $25 \%$.according to Transparency International overview Himachal Pradesh was positioned the second-least degenerate state in the nation, after Kerala. Add up to range of state is $55,673 \mathrm{~km}$.according to 2011 aggregate populace of the state was $6,864,602$.having education rate $82.80 \%$.total number of towns are 20,118 .

In year 1994, Lead and resources centre CORD Sidhbari started the idea of the self improvement gathering. The essential logic of string was in charge of the development and reinforcing of Self-Help Groups. Rope trusts that "if the women have cash in their grasp" it prompts better and noble lives. SHG advances confidence by creating its own particular assets, as opposed to staying in the different cycle of obligation.
In 1999 NABARD (National Bank for Agriculture and Rural Development) assigned CORD as the "Mother NGO" for the Self Help Group and allotted errands to help give preparing at all levels to Northern States, for example, Himachal Pradesh, Punjab Haryana and Jammu and Kashmir. String Sidhbari has framed and reinforced 1470 Self-Help Group in 562 towns of District Kangra of Himachal Pradesh which comprise of more than 222000 women individuals from poor and minimized groups of the aggregate SHG reserve funds and bank advance Rupees 23 crores available for use Rs 9450807 had been put by more than 13000 individuals in various types of salary creating exercises through group based business program in non-cultivate and associated rest of the advance has been used in home utilization social speculation like instruction, marriage, foundation building like toilets or house and so on.

\section{REVIEW LITERATURE}

Das (2015) title paper rise and exercises of SHGs - an awesome exertion and usage for women strengthening and rustic advancement. He found that SHGs are critical for improvement of rustic and poor women. SHGs are additionally expanded the sparing of the provincial women microfinance was great development by SHGs by methods for this salary level of SHGs are going on increment. Shetty (2016) revealed encourages assemble help to tackling the issue of lacking lodging and urban administration as a vital piece of neediness lightening programs. With the goal that self improvement gatherings helps in monetary consideration of rustic mass they likewise help the barred area of the general public. Maheswari and Goyal (2016) concluded in the paper title socioeconomic Empowerment of women through SHGs; an experimental examination. They had looked into on microfinance and women strengthening. Microfinance has contributed as an impetus of the social change and strengthening of poor women in India. Also it has made open door for advancement of pay producing exercises. Joining the SHG has given them enough certainty to talk, to approach, to be a section in family basic leadership, which is as far as anyone knows male space.

\section{RESEARCH METHODOLOGY:}

\section{Objectives of the study:}

1. To study the changes in the socio economic status of the women members of the SHGs. 
2. To study the impact of bank linkage with Self Help Groups in making women economically empowered.

3. To identify the impact of SHG- Bank linkage programme on political knowledge of SHG women members in the study area.

\section{Data Collection:}

\section{Primary Data}

Primary data: it refers to the statistical material which researcher originates for him for the purpose of the enquiry in hand. The primary data for the study is collected through questionnaire and interviewing the various members of SHGs in Hamirpur District of Himachal Pradesh.

\section{Secondary Data}

The researcher use both secondary data as well as primary data in order to get a better understanding about concept of socio-economic condition of the SHGs and its members. Secondary data is important and essential to build a theoretical foundation of the theme under study. the secondary or data was collected from the published sources such as Journals, News papers, Official websites DRDA of H.P. government, hprural.nic.in and NABARD have been represented for secondary data .

\section{Sample and Sampling Technique}

A sample of 30 SHG's was randomly selected. Information from 120 women members $(4$ members from each SHG's) were collected. Present study is based on multi stage sampling. The primary data was collected from the women members through standard questionnaire and survey method using personal interview schedule.

\section{FINDINGS AND DISCUSSION}

\section{A) Socio Economic Status of the Respondents}

Table 1- Age Group of the respondents

\begin{tabular}{|c|c|c|c|}
\hline $\begin{array}{c}\text { Sr. } \\
\text { No }\end{array}$ & $\begin{array}{c}\text { Age } \\
\text { Group }\end{array}$ & $\begin{array}{c}\text { No. of } \\
\text { Respondents }\end{array}$ & Percentage \\
\hline $\mathbf{1}$ & $18-25$ & 15 & 12.5 \\
\hline $\mathbf{2}$ & $26-35$ & 59 & 49.1 \\
\hline $\mathbf{3}$ & $36-45$ & 31 & 25.8 \\
\hline $\mathbf{4}$ & $46-55$ & 10 & 8.3 \\
\hline $\mathbf{5}$ & Above 55 & 5 & 4.2 \\
\hline & Total & $\mathbf{1 2 0}$ & $\mathbf{1 0 0}$ \\
\hline
\end{tabular}

Table 1 shows the data on the basis of age group of the women respondents. Clearly we can depict that majority of women respondents are $49.1 \%$ and $25.8 \%$ from age group 26-35 and 36-45 years respectively. Moreover, the table shows that SHGs-Bank Linkage programme is not preferred by the women in the age group of below 20 and above 50. As senior women are mostly feel financially insecure.

Table 2- Marital Status

\begin{tabular}{|c|c|c|c|}
\hline $\begin{array}{c}\text { Sr. } \\
\text { No. }\end{array}$ & Status & $\begin{array}{c}\text { No. of } \\
\text { respondents }\end{array}$ & Percentage \\
\hline $\mathbf{1}$ & Married & 111 & 92.5 \\
\hline $\mathbf{2}$ & Unmarried & 0 & 0 \\
\hline $\mathbf{3}$ & $\begin{array}{c}\text { Separated and } \\
\text { Window }\end{array}$ & 8 & 7.5 \\
\hline Ent & Total & $\mathbf{1 2 0}$ & $\mathbf{1 0 0}$ \\
\hline
\end{tabular}

Table 2 depicts that SHGs-Bank Linkage programs are very useful in economic enhancement of married women. Majority of the women respondents are married with $92.5 \%$, single women are not interested in SHGs and $8 \%$ of the women respondents are separated and widows.

\section{Table 3- Family annual income}

\begin{tabular}{|c|c|c|c|}
\hline $\begin{array}{c}\text { Sr. } \\
\text { No. }\end{array}$ & $\begin{array}{c}\text { Annual } \\
\text { Income }\end{array}$ & $\begin{array}{c}\text { No. of } \\
\text { respondents }\end{array}$ & Percentage \\
\hline $\mathbf{1}$ & $\begin{array}{c}\text { Below } \\
\text { Rs. } 40,000\end{array}$ & 18 & 15.1 \\
\hline $\mathbf{2}$ & $\begin{array}{c}\text { Rs. } 40.001- \\
\text { Rs.60,000 }\end{array}$ & 90 & 75 \\
\hline $\mathbf{3}$ & $\begin{array}{c}\text { Rs. } 60,001- \\
\text { Rs. } 85,000\end{array}$ & 10 & 8.3 \\
\hline $\mathbf{4}$ & Above 85,000 & 2 & 1.6 \\
\hline & Total & $\mathbf{1 2 0}$ & $\mathbf{1 0 0}$ \\
\hline
\end{tabular}

Table 3 shows that SHG members are from the family whose annual income is less that Rs. 60,000 only. Whereas, women from family's having annual income are not interested in joining Self Help Groups. As per analysis poor family members are always willing to join SHG's.

\section{B) Impact of Bank Linkage in Economic Upliftment}


International Journal of Trend in Scientific Research and Development (IJTSRD) ISSN: 2456-6470

Table 4 - Impact of SHGs-Bank Linkage on the Income Level

\begin{tabular}{|c|c|c|c|}
\hline $\begin{array}{c}\text { Sr. } \\
\text { No. }\end{array}$ & Opinion & $\begin{array}{c}\text { No. of } \\
\text { Respondents }\end{array}$ & Percentage \\
\hline $\mathbf{1}$ & Yes & 91 & 75.8 \\
\hline $\mathbf{2}$ & Can't say & 29 & 24.2 \\
\hline & Total & $\mathbf{1 2 0}$ & $\mathbf{1 0 0}$ \\
\hline
\end{tabular}

Table 4 shows that SHGs have brought a significant improvement in the income level of the respondents. $75.8 \%$ of the respondent's women have experienced an increase in their income level after joining SHGs. whereas only $24.2 \%$ of respondents said that they have not realized yet the impact of SHG-Bank Linkage programme on their income level.

Table 5- Change in Saving Pattern

\begin{tabular}{|c|c|c|c|c|c|}
\hline $\begin{array}{l}\text { Sr. } \\
\text { No. }\end{array}$ & Particulars & $\begin{array}{l}\text { Pre SHG } \\
\text { respondents }\end{array}$ & Percentage & $\begin{array}{l}\text { Post SHG } \\
\text { respondents }\end{array}$ & Percentage \\
\hline 1 & In SHGs & 0 & 80 & 120 & 100 \\
\hline 2 & $\begin{array}{c}\text { Personal } \\
\text { accounts in } \\
\text { banks }\end{array}$ & & 0 & 25 & 20.8 \\
\hline 3 & $\begin{array}{c}\text { No Savings } \\
\text { Total }\end{array}$ & \begin{tabular}{|l}
120 \\
120
\end{tabular} & $\begin{array}{l}100 \\
\mathbf{1 0 0}\end{array}$ & 0 & 0 \\
\hline
\end{tabular}

Table 5 clearly shows that none of the women had any kind of saving before joining the SHGs. whereas after joining SHG, every member as part of the mandatory saving of the group are saving in the group account of the SHGs. Therefore joining SHG gives a $100 \%$ positive impact in the saving nature of the respondents. But, only $20.8 \%$ percent the women are having own bank account along with the mandatory saving of the group.

\section{C) Impact of the political knowledge on the SHG's member.}

\section{Table 6- Impact of the political knowledge}

\begin{tabular}{|l|l|l|l|}
\hline $\begin{array}{l}\text { Sr. } \\
\text { No }\end{array}$ & $\begin{array}{l}\text { Political } \\
\text { Knowled } \\
\text { ge }\end{array}$ & $\begin{array}{l}\text { No. of } \\
\text { Responden } \\
\text { ts }\end{array}$ & $\begin{array}{l}\text { Percent } \\
\text { age }\end{array}$ \\
\hline $\mathbf{1}$ & Improved & 96 & 80 \\
\hline $\mathbf{2}$ & Not improved & 24 & 20 \\
\hline & Total & $\mathbf{1 2 0}$ & $\mathbf{1 0 0}$ \\
\hline
\end{tabular}

Table 6 shows that SHGs-Bank Linkage programmes have surely improved the political knowledge of the group members. After joining SHGs, members have to attend various formal and informal meetings organized at the block level. $80 \%$ of the SHGs respondents have admitted that their political knowledge on different government scheme has improved after joining SHGs. Only 20\% said that their political knowledge have not improved so far.

\section{SUGGESTIONS:}

- Unemployedand educated women should also participate in such programmes.

- Senior women should be motivated to participate in these programmes as they have good experience of life which is beneficial for the groups.

- The group members should consider SHGs as an opportunity to improve their socioeconomic conditions, but not only the means of taking easy loan or credit.

- For the success of SHGs-Bank Linkage programme, the government have to provide proper initiatives in rural as well as backward areas.

\section{CONCLUSION:}

Women empowerment is a progressing procedure. Subsequent to joining the Self Help Groups women respondents discovered them all the more monetarily and socially engaged. The self improvement gathering enhanced their financial parameters like independence, certainty, self ward and teaching to the young lady youngster. This can likewise be inferred that the SHGs-Bank Linkage Program (BLP) if executed and use appropriately, it can change the state of rustic economy of India. In the above investigation, we can state that the program can make some kind of progress as far as salary era for the poor women in country regions however it has neglected to 
upgrade the wage of the respondent to some degree which empowers them to think for sparing. The political power and information of the women have reliably enhanced with the bank linkage program.

\section{REFERNCES}

1) Das, R. (2015). Emergence and Activities of Self-Help Group (SHG)-A Great Effort and Implementation for Women's Empowerment as well as Rural Development: A Study on Khejuri CD Blocks in PurbaMedinipur, West Bengal. International Journal of Innovative Research and Development, 4(1).

2) Maheshwari, M., \&Goyal, S. (2016). SocioEconomic Empowerment of Women through Self Help Groups: An Empirical Analysis. Pacific Business International, 8(8), 87-100.

3) Shetty, M. M. A. (2016). A Study on Role of Shgs in Financial Inclusion of Excluded Section of the Society with Special Reference to Udupi District. Global Journal of Finance and Management, 8(1), 89-95.

4) Kothari, C. R. (2004). Research methodology: Methods and techniques. New Age International.

5) Manjula N Savadi, Dr. Honnappa S, Role of micro finance in women's empowerment: A case study in Vijayapur district, International Journal of Applied Research, 2016; 2(3): 342-346.

6) DRDA \& hprural.nic.in.

7) Newspaper and Officials of NABARD.

8) Censusindia.gov.in

9) Women's SHGs and Managing convergence in Himachal Pradesh Department of Women and Child Development, Ministry of HRD.

10) https://en.wikipedia.org/wiki/Working_poor 